\title{
NCKIPSD wt Allele
}

National Cancer Institute

\section{Source}

National Cancer Institute. NCKIPSD wt Allele. NCI Thesaurus. Code C97434.

Human NCKIPSD wild-type allele is located in the vicinity of 3p21 and is approximately 22 $\mathrm{kb}$ in length. This allele, which encodes NCK-interacting protein with SH3 domain, is involved in signal transduction and stress fiber formation. A chromosomal translocation $t(3 ; 11)(p 21 ; q 23)$ of the gene with the MLL gene is associated with therapy-related leukemia. 